\title{
Deuteronomy's concept of life in Hebrews
}

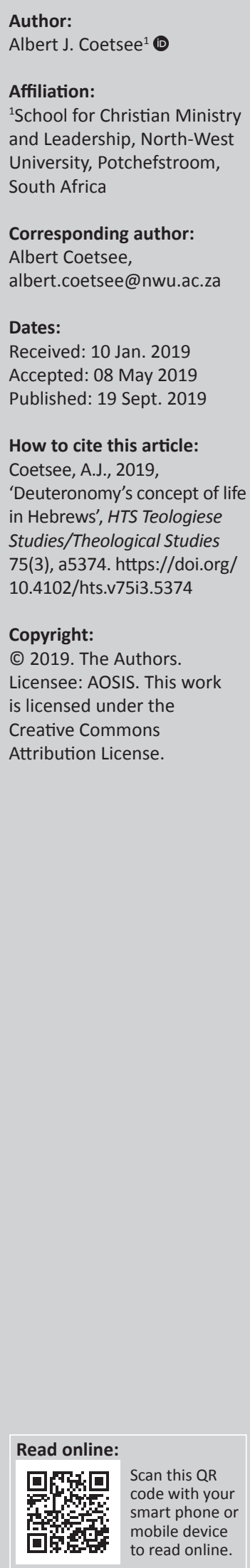

This article endeavours to contribute to the study of the influence and effect of Deuteronomy in the book of Hebrews. It investigates the possible influence of one of Deuteronomy's key concepts on Hebrews, namely, the concept of 'life'. The article starts off by defining the multifaceted concept of 'life' in Deuteronomy. This is followed up by combing through the text of Hebrews to identify traces of this concept in the words and arguments that the writer employs. The possible traces found are then investigated intertextually in detail. This includes references to 'the living God' (Heb 3:12; 9:14; 10:31; 12:22), God's 'living and active' word (Heb 4:12), 'the new and living way' Jesus opened through his death (Heb 10:20) and the command to 'submit to the Father of spirits and live' (Heb 12:9). The article concludes by synthesising the findings to discuss whether Hebrews deliberately employs Deuteronomy's concept of life.

Keywords: Deuteronomy; Hebrews; Life; Live; Living; Alive; Intertextual.

\section{Introduction}

As could be expected of a New Testament book drenched in references and allusions to the Old Testament, a legion of studies have been penned on the use of the Old Testament in Hebrews. ${ }^{1}$ A number of studies contribute to this field by investigating the occurrence and function of individual Old Testament books in Hebrews. Like the rest of the New Testament, the Old Testament books that feature the most prominently in Hebrews are the Psalms, Isaiah and Deuteronomy. ${ }^{2}$ This article endeavours to contribute to the study of the influence and effect of Deuteronomy in Hebrews.

A couple of groundbreaking studies have been done in this regard, including the following:

- Katz (1958:213-223) investigates the probable Vorlage of quotations from Deuteronomy in Hebrews, focusing especially on Hebrews 12:15.

- Steyn (2007:152-168) gives a synopsis of quotations, references and allusions attributed to Deuteronomy, as well as a brief discussion of certain motifs from Deuteronomy in Hebrews, namely, covenant, Moses and priesthood.

- Allen (2007a), in his very informative PhD thesis, investigates the way in which the book of Deuteronomy operates within the paraenetic sections of Hebrews, and argues that Hebrews becomes a 'new' Deuteronomy.

- Kibbe (2016) focuses on the depiction of the Sinai theophanies of Exodus 19 and Deuteronomy 5 in Hebrews 12:18-29, and investigates why it seems as if the author of Hebrews misunderstood or manipulated these sources. ${ }^{3}$

This article investigates the possible influence of Deuteronomy's concept of 'life' in Hebrews. References to 'life' are found throughout Deuteronomy. Markl (2014:71), who outlines 'life' (חיה) in Deuteronomy, calls it 'one of the key theological concepts in the book'. Because the influence of certain motifs from Deuteronomy in Hebrews has already been proven, the question arises whether traces of the influence of Deuteronomy's concept of life can also be found in Hebrews. This is the question the article aims to answer.

This article starts off by defining the multifaceted concept of 'life' in Deuteronomy in both the MT and LXX. This is followed up by combing through the text of Hebrews to identify traces of

1.See footnotes 7 to 14 in Allen (2007a:2-4) for an excellent survey of studies on the use of the Old Testament in Hebrews. For a more recent survey of the topic, see Dyer (2013:112-122).

2.For studies on the use and influence of the Psalms, Isaiah and Deuteronomy in the New Testament, see three publications in the The New Testament and the Scriptures of Israel series edited by Moyise and Menken, namely, The Psalms in the New Testament (2004), Isaiah in the New Testament (2005) and Deuteronomy in the New Testament (2007).

3.To this list can be added the study guide of Smith (2012), who compares Deuteronomy and Hebrews.

Note: The collection entitled 'Eben Scheffler Festschrift', sub-edited by Jurie H. le Roux (University of Pretoria) and Christo Lombaard (University of South Africa). 
this concept in the words and phrases that the writer employs. Next, the probable traces found are investigated intertextually in detail. ${ }^{4}$ The article concludes by synthesising the findings to discuss whether Hebrews deliberately employs Deuteronomy's concept of life.

\section{The multifaceted concept of 'life' in Deuteronomy Deuteronomy's concept of 'life' in the MT}

In another article, I give a survey of the different ways in which the concept of life [חיה] is employed in Deuteronomy (Coetsee 2019). The study finds that the root חיה is found 39 times in the book of Deuteronomy, consisting of the verb חָיָָ (18x; 'live'), the adjective '

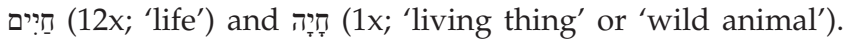
Moreover, the study finds that the 39 occurrences of 'life' in Deuteronomy are employed in the following eight ways:

1. Life as a result of obedience: The most unique employment of the concept of life in Deuteronomy is occurrences where life is described as the consequence or result of keeping YHWH's commandments. Eleven such occurrences are found in Deuteronomy $(4: 1 ; 5: 33 ; 6: 24$; $\left.8: 1 ; 16: 20 ; 30: 6,15,16,19^{3 x}\right)$.

2. Physical life: Most of the references to life in Deuteronomy refer to physical life (albeit in a variety of ways). Fourteen such references are found $\left(4: 4,33,42 ; 5: 3,24,26^{\text {b }} ; 8: 3^{\text {a }}\right.$; $\left.19: 4,5 ; 20: 16 ; 28: 66^{\mathrm{ab}} ; 31: 27 ; 33: 6\right)$.

3. Lifespan: Seven times the concept of life is used in Deuteronomy to refer to the length of time someone lives $(4: 9,10 ; 6: 2 ; 12: 1 ; 16: 3 ; 17: 19 ; 31: 13)$.

4. The living God: Two passages in Deuteronomy refer to YHWH as 'living' (5:26a ; 32:40).

5. Wild animals: Deuteronomy employs the concept of life once to refer to 'wild animals' (7:22).

6. YHWH's revealed will as source of life: $Y H W H ' s$ revealed will is indicated as the source of life twice in Deuteronomy (8:3 $; 32: 47)$.

7. YHWH and obedience as source of life: Closely linked to the previous employment, Deuteronomy refers once to YHWH and obedience as source of life (30:20).

8. YHWH has power over life: One passage in Deuteronomy describes $\mathrm{YHWH}$ as the one who has power over life (32:39).

\section{Deuteronomy's concept of 'life' in the LXX}

It is universally accepted that quotations from and allusions to the Old Testament in Hebrews do not come from the MT, but from some form of the LXX. ${ }^{5}$ This necessitates a synopsis of Deuteronomy's concept of life in the LXX.

The first question that needs to be answered is which Greek version of Deuteronomy was available and used by the writer

4.In this article, intertextuality is used in the broad terms spelled out by Oropeza and Moyise (2016:xiii), namely, 'the study of how a given text is connected with other texts [broadly understood] outside of itself and how those texts affect the texts [broadly understood] outsio

5.See the very informative studies of Gheorghita (2003), Rascher (2007) and Docherty (2009). of Hebrews. The answer, despite various studies in this regard (Steyn 2007:168; cf. Katz 1958:213-223), is still elusive. Allen (2007a:8-9), in his monumental study of Deuteronomy in Hebrews, chooses to make use of Wevers' critical edition. For the purposes of this study, I do the same, yet making use of the second edition (2006).

Tracing the concept of life in LXX, Deuteronomy delivers the following results:

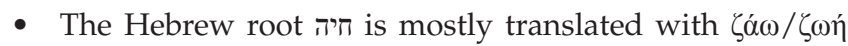
in the LXX. Of the 39 occurrences of חיה in the MT, 36 are

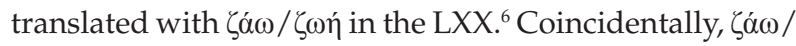
$\zeta \omega \eta$ is still found 39 times in the LXX. Preference is given to the verb $\zeta \dot{\alpha} \omega$, which is found 28 times, ${ }^{7}$ while the noun $\zeta \omega \eta$ is found 11 times. $^{8}$

- Comparing the MT with the LXX, there are seven exceptions when it comes to Deuteronomy's concept of life. ${ }^{9}$ There are three instances where the MT is not

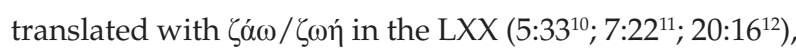
two occurrences of $\zeta \alpha \dot{\alpha} \omega$ in the LXX that do not have a equivalent in the MT $\left(11: 8^{13} ; 12: 19^{14}\right)$, one instance where the LXX adds another occurrence of $\zeta \alpha$ coin a verse already containing this verb $(4: 33)^{15}$ and one instance where the subject or source of life is changed, and consequently the interpretation of the reference (30:20). ${ }^{16}$

Consequently, Deuteronomy's concept of life as found in the MT is fundamentally still evident in the LXX. The LXX retains six of the eight ways in which MT Deuteronomy employs the concept of life, which can be listed as follows:

6.Deuteronomy $4: 1,4,9,10,33,42 ; 5: 3,24,26^{2} ; 6: 2,24 ; 8: 1,32 ; 12: 1 ; 16: 3,20 ; 17: 19$ $19: 4,5 ; 28: 66^{2} ; 30: 6,15,16,19^{3}, 20 ; 31: 13,27 ; 32: 39,40,47 ; 33: 6$.

7.Deuteronomy $4: 1,4,10,33^{2}, 42 ; 5: 3,24,26^{2} ; 6: 24 ; 8: 1,3^{2} ; 11: 8 ; 12: 1,19 ; 16: 20$ $19: 4,5 ; 30: 6,16,19 ; 31: 13,27 ; 32: 39,40 ; 33: 6$.

8.Deuteronomy 4:9; 6:2; 16:3; 17:19; 28:66²; 30:15, $19^{2}, 20 ; 32: 47$.

9.There are various smaller differences in the wording of Deuteronomy in Rahlfs' (1996) and Wevers's edition (2006). These differences do not pertain to or influence the concept of life (e.g. 4:1, 10; 6:24; 8:1, 3; 12:1; 17:19; 19:4; 30:16; 32:40, 47), and the concept of life (e.g. $4: 1,10 ; 6: 24 ; 8: 1$,
are consequently not discussed here.

10.According to the MT, the result of Israel's obedience will be life ('that you may live',

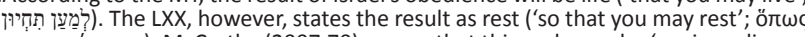

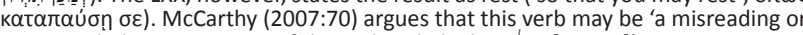
an expanded interpretation of the verb as linked to $\sqrt{ }$ [to rest]'.

11.The noun חִיזה [wild animals] is translated with Onpiov in Greek, the exact word found in Deuteronomy 7:22 in the LXX.

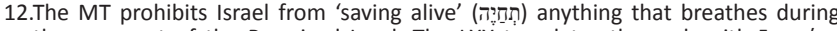
the conquest of the Promised Land. The LXX translates the verb with $\zeta \omega \gamma \rho \varepsilon \dot{\omega} \omega$, which has the same nuance as the verb in the MT, namely, 'to take/capture alive' (cf. Bauer et al. 2000:429; Liddell, Scott \& Jones 1996:758).

13. Deuteronomy 11:8 in the MT states that Israel's obedience will result in them being

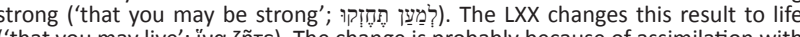
('that you may live'; iva $\zeta \tilde{n} \tau \varepsilon)$. The change is probably because of assimilation with Deuteronomy 8:1 (cf. McCarthy 2007:82; Weinfeld 1991:432)

14.The MT of Deuteronomy 12:19 commands Israel not to neglect the Levite 'all your

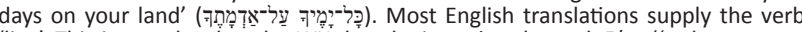
'live'. This is exactly what the LXX does by inserting the verb ¿áw ('as long as you

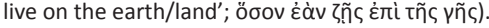

15.Probably because of assimilation with 5:26, the LXX changes the vague reference

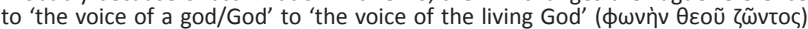
in $4: 33$.

16.Deuteronomy 30:20's ambiguous reference to 'he/it (הוֹא) is your life', which

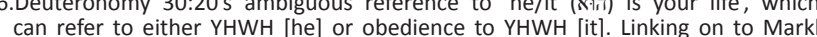
$(2014: 86)$, I argue that the MT is deliberately vague to refer to both. The LXX, however, translates the phrase as 'this is our life' (тoũto ì $\zeta \omega n$ ), opting for the second interpretation. 
1. Life as a result of obedience (12x): $4: 1 ; 6: 24 ; 8: 1 ; 11: 8 ; 16: 20$; $30: 6,15,16,19^{3 x}, 20$.

2. Physical life (13x): 4:4, 33, $42 ; 5: 3,24,26^{\mathrm{b}} ; 8: 3^{\mathrm{a}} ; 19: 4,5$; $28: 66^{\mathrm{ab}} ; 31: 27 ; 33: 6$.

3. Lifespan (8x): 4:9, 10; 6:2; 12:1,19; 16:3; 17:19; 31:13.

4. The living God (3x): 4:33a ; 5:26a; 32:40.

5. YHWH's revealed will as source of life $(2 \mathrm{x}): 8: 3^{\mathrm{b}} ; 32: 47$.

6. YHWH has power over life (1x): 32:39.

\section{Traces of Deuteronomy's concept of life in Hebrews}

Keeping in mind the six ways in which LXX Deuteronomy employs the concept of life, this section endeavours to comb through the text of Hebrews from beginning to end to identify traces of this concept in the words and arguments that the writer employs. A distinction will be made between highly unlikely, unlikely and possible traces. Although any classification of this sort is open for debate (like the distinction between quotations and allusions in Hebrews), the numerous references to the concept of life in Hebrews necessitate it. The parameters for this classification are the following:

- Highly unlikely traces: References to the concept of life in general with no explicit or implicit references to Deuteronomy.

- Unlikely traces: References to the concept of life that may indirectly be traced to Deuteronomy, but that are not probable.

- Possible traces: References to the concept of life that may have Deuteronomy as background.

\section{Highly unlikely traces of Deuteronomy's concept of life in Hebrews}

As expected, Hebrews contains a number of references to physical life $(7: 8 ; 9: 17)$ and lifespan $(2: 15 ; 5: 7 ; 7: 3 ; 11: 22)$. However, these references do not have Deuteronomy as background. This is not strange because references to life and death ${ }^{17}$ are quite common in the literature.

Hebrews also contains numerous references that link on to the concept of life, although it does not refer to life per se. This includes the following:

- Creation $(1: 2,10 ; 2: 10 ; 3: 4 ; 4: 3 ; 9: 11,26 ; 11: 3)$.

- The preservation of creation (1:3).

- God being the Father of his Son $(1: 5 ; 5: 5)$.

- The eternality of the Son $(1: 11-12 ; 7: 16,24,25)$.

- The death of the Son $(2: 9,14 ; 9: 15)$.

- The incarnation of the Son $(2: 14 ; 10: 5) .{ }^{18}$

- The devil having power over death $(2: 14)$.

- The eternal priesthood of the Son $(5: 6 ; 7: 17,21)$.

- Dead works $(6: 1 ; 9: 14)$.

- Resurrection (6:2; 11:19; 11:35).

17. Hebrews contains various references to death (e.g. $2: 15 ; 5: 7 ; 7: 8,23 ; 9: 16,17,27$ $10: 28 ; 11: 4,5,12,13,21$ )

18.At first sight, the introductory phrase of Hebrews 1:6 might be interpreted as a reference to the Son's incarnation. Ellingworth (1993:117-118), however, argues convincingly that the phrase refers to God bringing his Son 'out of death into the glory of the heavenly assembly'.
- The eternal priesthood of Melchizedek (7:3).

- The growing old of the covenant (8:13).

- The eternality of the Spirit (9:14).

- Living by faith (10:38).

- The existence of God (11:6).

- Old age (11:11).

- Birth (11:23).

- The resurrection of the Son (13:20).

It is highly unlikely that any of these references contain traces of Deuteronomy's concept of life. The writer of Hebrews mainly employs the concept of life and death in reference to the Son, which has no parallels with Deuteronomy.

\section{Unlikely traces of Deuteronomy's concept of life in Hebrews}

Above, 'unlikely traces' were defined as references to the concept of life in Hebrews that may indirectly be traced to Deuteronomy, but that are not probable. Six such traces are discussed.

\section{Death as capital punishment for disobedience to YHWH}

Although the scope of this study does not include references to death in Deuteronomy, it should be noted that Deuteronomy employs the root מות ('die', 'death') most often to refer to capital punishment for disobedience to YHWH. ${ }^{19}$ Hebrews contains a couple of references that may have capital punishment for disobedience as background (e.g. Heb 6:1; 10:28), especially when referring to the Son's substitutionary death (e.g. Heb 2:9, 14; 9:14-15).

However, it is difficult to link these references to a single or specific transgression that deserves death according to Deuteronomy. Moreover, Deuteronomy is not the only book in the Pentateuch that contains laws that stipulate that disobedience to $\mathrm{YHWH}$ deserves death.

\section{The hardening of hearts (Heb 3:7-4:11)}

Because of the parallel formed by the call to obedience and the reference to the heart, Hebrews 3:7-4:11's exhortation not to harden hearts may echo Deuteronomy 30:6's reference to the circumcision of hearts. In Deuteronomy 30:6, YHWH promises Israel that he will someday remove whatever prevents them from following his laws and decrees (Tigay 1996:285), which will enable them to live.

Yet, Hebrews does not refer to a circumcision of heart or loving God with heart and soul. Moreover, references to hardening the heart come from the quotation of Psalm 95, which, in its turn, builds on Israel's rebellion in the wilderness as described in Numbers $14 .^{20}$ This makes it unlikely that Deuteronomy 30:6 is the background of Hebrews 3:7-4:11.

19.cf. Deuteronomy $9: 28 ; 13: 5,9,10 ; 17: 5,6,7,12 ; 18: 20 ; 19: 11,12 ; 21: 21,22 ; 22: 21$, $22,24,25,26 ; 24: 7,16$.

20.Although Allen (2007b:129-149) convinces with his argument that Psalm 95 has a Deuteronomic flavour, Kibbe (2016:126-127) is correct when he argues that
a Hebrews comes to Deuteronomy by way of Psalm 95, and not the other way around. 


\section{Living on milk (Heb 5:13)}

Just like Deuteronomy 8:3, Hebrews 5:13 contains the metaphor of 'living on' something. While Hebrews 5:13

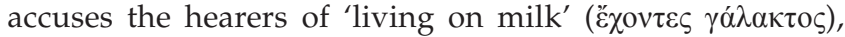
Deuteronomy 8:3 states that YHWH taught the Israelites in the wilderness that 'man does not live by bread alone, but from every word that comes from the mouth of the Lord' $(\dot{\varepsilon} \pi \hat{\imath}+$ dative $+\zeta \dot{\eta} \sigma \varepsilon \tau \alpha \iota)$.

However, the parallel is only superficial. In the first place, the verb used is not the same. Secondly, while Hebrews talks negatively about living on milk, Deuteronomy speaks positively about living from everything that comes from the mouth of YHWH.

\section{Tasting the word of God (Heb 6:5)}

Hebrews 6:5 may also be linked to Deuteronomy 8:3. The former describes 'tasting the goodness of the word of God'

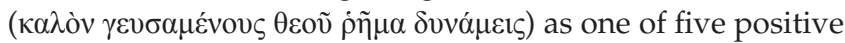
Christian experiences. What this phrase has in its favour in terms of parallels with Deuteronomy 8:3 is the object: the word of God. What counts significantly against it is the verb: 'taste' (or 'partake of'; $\gamma \varepsilon v$ oual; cf. Bauer et al. 2000:195) is not the same as 'living on', which makes it improbable that Deuteronomy 8:3 is the background of Hebrews 6:5.

\section{Laws on hearts (Heb 8:10; 10:16)}

In the midst of this quotation of Jeremiah 31:31-34 (LXX 38:31-34) in Hebrews 8:8-12, YHWH promises that with the new covenant he will put his laws into his people's

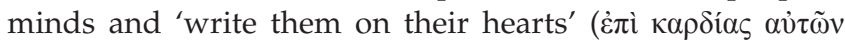

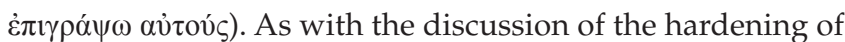
hearts above, these words have a faint resonance with Deuteronomy 30:6, where YHWH promises that he will circumcise his people's hearts so that they will be able to obey him. However, the quotation clearly comes from Jeremiah 31, and Hebrews 8:10 and 10:16 contains no reference to circumcision, love or life.

\section{Equipped to do his will (Heb 13:21)}

The writer's prayer for his addressees in his final benediction is that God equips them with everything good so that they may do his will (Heb 13:21). Although this does not contain a reference to life, once again it has a superficial parallel with Deuteronomy 30:6. Both references boil down to God enabling his people to do his will. However, once more Hebrews 13:21 does not contain a reference to circumcision, and the essence of Deuteronomy 30:6 is completely different: it is not a prayer or a benediction, but a factual description. Moreover, the prayer that God enables his church to do his will is common in the New Testament. ${ }^{21}$

\section{Possible traces of Deuteronomy's concept of life in Hebrews}

Of the six different ways in which the concept of 'life' is employed in LXX Deuteronomy, the most likely references to be traced to Deuteronomy are references that refer to (1) life as a result of obedience, (2) the living God, (3) YHWH's revealed will as source of life and (4) YHWH having power over life. Although these employments of the concept of life can be traced to other books of the Old Testament, they are Deuteronomic and call for further investigation.

The following references to life in Hebrews may have Deuteronomy as background:

1. 'The living God' (Heb 3:12; 9:14; 10:31; 12:22): The phrase 'the living God' ( $\theta \varepsilon$ ó $\zeta \zeta \tilde{\omega} v)$ is found four times in Hebrews. This phrase has a direct parallel with Deuteronomy 4:33 and 5:26, where YHWH is referred to as 'the living God'. This raises the question: Does one or both of these references form the background of any or all of the references to 'the living God' in Hebrews? It does not necessarily have to be the case because the phrase 'the living God' is found throughout the Old Testament. ${ }^{22}$ Consequently, references to 'the living God' in Hebrews call for further investigation.

2. 'The word of God is living and active' (Heb 4:12): The

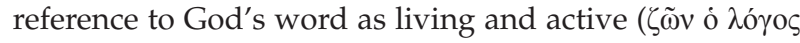

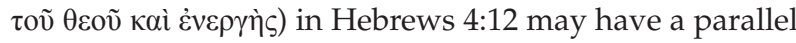
with Deuteronomy 32:47, where Moses calls the words he spoke to them 'no empty word for you, but your very life

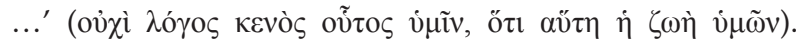
Although this by no means forms a direct parallel, the verbal analogy formed by 'word' ( $\lambda$ ó $\% \varsigma$ ) and 'living/life' ( $\zeta \alpha \omega / \zeta \omega \eta ́)$ calls for further investigation.

3. 'The new and living way' (Heb 10:20): Hebrews 10:20's invitation to draw near to God with complete confidence

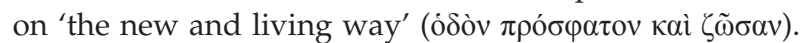
Christ opened up may have Deuteronomy 30:6 as background, where $\mathrm{YHWH}$ promises to enable his people in the future to live. This enablement may be pointed to in the overall argument of Hebrews 7:1-10:18. Consequently, 10:20 calls for further investigation.

4. 'Be subject to the Father of spirits and live' (Heb 12:9): Hebrews 12:9's exhortation to 'be subject to the Father of

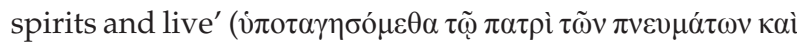

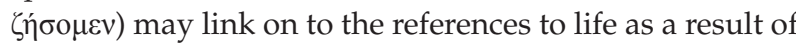
obedience in Deuteronomy (cf. 4:1; 6:24; 8:1; 11:8; 16:20; $\left.30: 6,15,16,19^{3 x}, 20\right)$.

These references will be investigated intertextually in detail in the next section.

\section{An intertextual investigation of the possible traces of Deuteronomy's concept of life in Hebrews}

The aim of this section is to investigate the possible traces of Deuteronomy's concept of life in Hebrews intertextually in detail. Investigation will begin either with the text of Hebrews or LXX Deuteronomy, depending on what serves comparison the best. This will then be compared Isaiah 37:4,17; Jeremiah 10:10; 23:36; Daniel 6:20,26; Hosea 1:10. 
with and checked against the relevant word(s)/phrase(s) in the remaining book. Other possible backgrounds for the $\operatorname{word}(\mathrm{s}) /$ phrase(s) under discussion will also be investigated. In doing so, the argument that Deuteronomy forms the background of the specific reference to life in Hebrews will be weighed.

\section{The living God (3:12; 9:14; 10:31; 12:22)}

To determine if Deuteronomy forms the background of the four references to 'the living God' in Hebrews, the discussion starts by investigating the two references of this phrase in Deuteronomy.

\section{Deuteronomy 4:33 and 5:26}

LXX Deuteronomy's two references to 'the living God' are found in 4:33 and 5:26. The two references are almost verbatim, asking if any people ever heard the voice of the living God speaking out of the midst of the fire, as you have heard, and still live?'

Despite the similarities between the two, the context differs. In 4:33, Moses reminds Israel that their experience of God and his salvation is totally unique and without parallel. In 5:26, found in the epilogue to the Decalogue, Moses reminds Israel of their reaction when they heard the words of YHWH from mount Horeb. They were utterly terrified, and amazed by the fact that they heard the voice of 'the living God', and remained alive.

The phrase 'the living God' in Deuteronomy 4:33 and 5:26 is interpreted differently. Some view it as a description for the being of God; he is living (cf. Weinfeld 1991:324). Others view the phrase as making a contrast between the God of Israel and the idols of the nations. He alone can accomplish things; he alone is the 'living' God (cf. Gerleman 1997:416). Still others view the phrase as describing God as being actively at work or 'obviously present' with his people (cf. Ringgren 1980:338-339).

Although these interpretations are not mutually exclusive, the context of Deuteronomy 4 and 5 tips the scale slightly in favour of interpreting this phrase as making a contrast between Israel's God and the gods of the nations. Israel has experienced something that no other nation has experienced before. They heard God's voice! They heard him speak, and they were terrified, and yet they remained alive.

\section{Hebrews 3:12}

The first reference to 'the living God' is found in 3:12. After a lengthy quotation of Psalm 95:7b-11 (LXX 94:7b-11) in 3:7-11, the writer applies these verses to his hearers in 3:12-19 by elaborating on the results of Israel's unbelief and disobedience. He starts off in 3:12 by exhorting them to take care that none

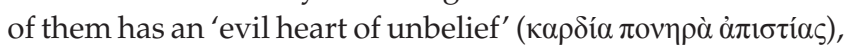

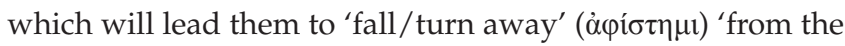

living God' (àrò $\theta \varepsilon o \tilde{~} \zeta \tilde{\omega} v \tau o \zeta)$. 'Falling away' from God is a phrase often found in the LXX, referring to apostasy. ${ }^{23}$

Deuteronomy 4 and 5 do not warn against to apostasy, but idolatry (cf. 4:35, 39; 5:7-10). Although there is some overlap between these concepts, they are not identical. Moreover, Hebrews 3:7-19 does not mention idols or the gods of the nations. Finally, no scholars were found who link Hebrews 3:12 with Deuteronomy 4:33 or 5:26. ${ }^{24}$ As a result, it is improbable that Deuteronomy $4: 33$ or $5: 26$ forms the background of the phrase 'the living God' in Hebrews 3:12.

\section{Hebrews 9:14}

The second reference to 'the living God' in Hebrews is found in 9:14. In Chapter 9, the writer's argument revolves around the insufficiency of the Old Testament sacrifices in contrast with the sufficiency of the sacrifice of Christ. The reference to 'the living God' is found right at the end of the conclusion of the a fortiori argument in 9:13-14, which makes a distinction between the outward purification made by animal sacrifices and the inward purification made by the sacrifice of Christ. Christ's sacrifice is said to purify the

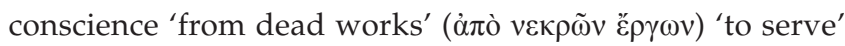

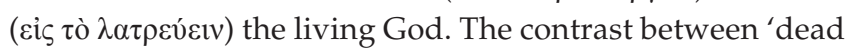
works' and 'the living God' is clear.

Apart from 9:14, Hebrews has a reference to 'dead works' in $6: 1$. Although some argue that the phrase refers to idolatry, there is nothing in 6:1 and 9:14 that limits it to idolatry (cf. Koester 2001:305). Rather, the context of both references supports the broader interpretation of 'dead works' as sin (cf. Attridge 1989:252). ${ }^{25}$

Because idolatry is not on the foreground in $6: 1$ or $9: 14$, and because neither Deuteronomy 4:33 nor 5:26 contain either a call to repentance (Heb 6) or prominent cultic imagery (Heb 9), the overlap between Deuteronomy's references to the living God and Hebrews 9:14 is faint and vague at best.

\section{Hebrews 10:31}

The third reference to 'the living God' is found in the final words of the writer's warning in Hebrews 10:26-31, which once more is a warning against apostasy.

At first glance, this reference to 'the living God' looks much more promising for the purposes of this study, primarily because 10:26-31 is drenched in Deuteronomy. It contains an

23.Ellingworth (1993:24) points out that 'falling away from the living God' is probably synonymous for 'hardening the heart'.

24.Ellingworth (1993:222) indicates the closest Old Testament parallel is Numbers

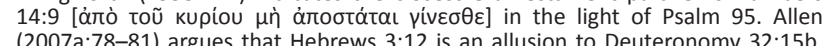
2007a:78-81) argues that Hebrews $3: 12$ is an allusion to Deuteronomy 32:15b. Guthrie $(2007: 920-921,953)$ argues that, apart from Psalm 95, the background of Hebrews 3:12-19 are various passages in the Old Testament on the wilderness
wanderings, among others Deuteronomy 9 (specifically 9:7, 23-24).

25. Hebrews 9:14 depicts sin in cultic terms, namely, defilement that obstructs one from approaching God (cf. Lane 1991:240). 
allusion to and two quotations from Deuteronomy. In 10:28, the reference to two or three witnesses is an allusion to Deuteronomy 17:6, ${ }^{26}$ and the two quotations in 10:30 come from Deuteronomy 32:35a and 32:36a, respectively. ${ }^{27}$ Consequently, it would not be strange if 10:31 in a way alludes to Deuteronomy as well.

Moreover, unlike the previous references to 'the living God' in Hebrews, the reference in 10:31 is used to evoke fear. The text itself describes the consequence of their conduct as 'fearful/frightful' ( understatement to say that the reference to 'falling into the hands' of God sounds ominous. In Deuteronomy 5:26, the reference to 'the living God' is also found in a context of fear. The passage describes the Israelites' terror when they heard the voice of God. ${ }^{28}$

However, a couple of factors count against viewing Deuteronomy 5:26 as the background of Hebrews 10:31. In the first place, Deuteronomy does not aim to evoke fear; it describes the fear of the Israelites at the Horeb theophany. ${ }^{29}$ Secondly, Deuteronomy 5 does not make mention of 'falling into the hands' of the living God.

There is another possibility. Because the two quotations found in Hebrews 10:30 come from consecutive verses in the Song of Moses (Dt 32), the possibility should be explored that the reference to 'the living God' derives from the Song as well, preferably a subsequent verse. This can be the case. Deuteronomy 32:40 contains an oath formula in

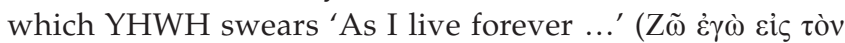
$\alpha i \tilde{\omega} v \alpha)$. What makes this possibility very alluring is the fact that the content of YHWH's oath has to do with judgement and vengeance (Dt 32:41-42), just like Hebrews 10:30-31. What counts against this interpretation is the fact that Hebrews 10:31 does not contain a reference to God's oath, and Deuteronomy 32:40-42 does not have the exact words 'the living God'. Nevertheless, the overlap in the theme of judgement and the fact that the words come from subsequent words of the Song of Moses convince various scholars that Deuteronomy 32:40-42 is the background of Hebrews 10:31..$^{30}$

Taking all things into account, this view is probably correct. Consequently, even though the investigation started off elsewhere, it seems that the first reference to Deuteronomy's concept of life in Hebrews has been found.

26. The allusion could also be to Deuteronomy 19:15 or Numbers 35:20, but Deuteronomy 17:6 'is the closest wording to Hebrews' (Ellingworth 1993:537). Guthrie (2007:979) argues that Hebrews 10:28 consists of a combination of two allusions, namely, Deuteronomy 17:2-7 and Deuteronomy 13:8.

27.The second quotation can also be from Psalms 135:14a (LXX 134:14a) because it is Deuteronomy 32:36a verbatim. It makes more sense that the latter is quoted here because it logically follows on Hebrews 10:30a's quote of Deuteronomy 32:35a.

28.In a brief remark, Allen (2007a:66-67) links Hebrews 10:31 with Deuteronomy 5:26 (wrongly indicated as 5:36).

29.For a good discussion on the type of fear Israel expressed in Deuteronomy, see Kibbe (2016:52-73).

30.Ellingworth (1993:537) views Hebrews 10:31 as 'a summary' of Deuteronomy 32:40f., while Cockerill (2012:494) views Deuteronomy 32:40-41 as the background of Hebrews 10:31.

\section{Hebrews 12:22}

The fourth and final reference to 'the living God' in Hebrews is found in 12:22. In Hebrews 12:18-24, the writer makes a sharp contrast between God's terrifying theophany at Sinai when he gave his law to Israel (12:18-21) and the addressees' joyous situation under the new covenant (12:22-24). Hebrews 12:22-24 contains seven or eight ${ }^{31}$ references to positive Christian privileges to which the addressees have now 'come' in Christ. The second of these is the reference to 'the city of

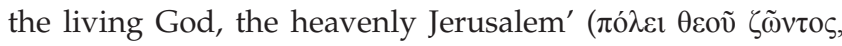

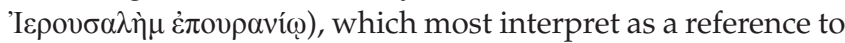
the heavenly city. Elsewhere the writer of Hebrews describes this as 'the city ... whose designer/architect and builder is God' (11:10), 'the city prepared by God' (11:16) and 'the city that is to come' $(13: 14) .^{32}$

There are two good reasons to view this phrase as an allusion to Deuteronomy 5:26:

- Firstly, background of 12:18-21 is clearly the description of YHWH's theophany at Sinai, recounted in Exodus 19-20 and Deuteronomy $4-5$. While the writer alludes to both, he primarily uses Deuteronomy $4-5$ as the background of his depiction of the Sinai event. The references to 'come' (

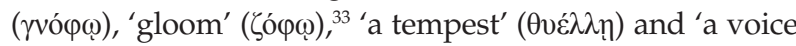
of words' ( $\varphi \omega v \tilde{n} \dot{\rho} \eta \mu \alpha \dot{\tau} \omega v)$ all come from Deuteronomy 4:11-12 and 5:22. Moreover, Moses' words 'I tremble with fear' (12:21) is an allusion to Deuteronomy 9:19, ${ }^{34}$ which the writer links to Deuteronomy 4 'on the basis of verbal analogy' (Guthrie 2007:988).

- Secondly, in the verses that follow (12:25-29), the writer concludes his fifth and final warning passage with the warning that 'God is a consuming fire' (ó $\theta$ \&ò $\zeta \dot{\eta} \mu \tilde{\omega} v$

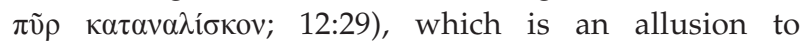
Deuteronomy 4:24.

Because multiple allusions to Deuteronomy $4-5$ are found in Hebrews 12:18-29, the possibility that Hebrews 12:22's reference to the 'living God' alludes to Deuteronomy 5:26 becomes a strong possibility (cf. Ellingworth 1993:677). Deuteronomy 5:26, however, does not mention a heavenly city. Nevertheless, Deuteronomy 5:26 may very well be the background for the phrase 'the living God' in Hebrews 12:22, taking into account that the writer of Hebrews uses the phrase for his own purposes.

\section{The word of God is living and active (4:12)}

Together with 4:13, 4:12 forms the conclusion of the writer's long and elaborate midrash on Psalm 95 (LXX 94) in 3:7-4:11,

31.These references are all in the form of datives of destination. The interpretation of the use of kai in the passage (used explicatively or to refer to separate items) determines the number of references identified.

32.To this can probably be added 'the rest' that remains for those who persevere (3:7-4:11), and the reference to 'a kingdom that cannot be shaken' (12:28).

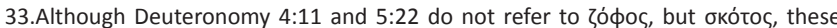
words are close synonyms. The writer of Hebrews probably replaced бкótoc with そóфoৎ (cf. Attridge 1989:373).

34.Allen (2007a:67-72), however, views Hebrews $12: 21$ as a quotation from Deuteronomy 9:19. 
in which he addresses the problem of hearts being hardened and the urgent need to listen to God's voice 'today'. In 4:12, the writer underscores that God's word is performative. ${ }^{35}$ The living God's word is 'living and active', able to discern and expose the motifs and intentions of the heart (Ellingworth 1993:261; cf. Smillie 2004:347-348). Just like God's word exposed the Israelites' hearts in the wilderness, so it discerns and exposes the hearts of the addressees.

From the immediate context, 'the word of God' links with Psalm 95:7's reference to God's voice (cf. Weiss 1991:284). ${ }^{36}$

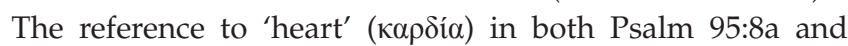
Hebrews 4:12 supports this interpretation. The immediate context of 4:12-13 and the overall argument of Hebrews may even broaden the scope of this 'word' to include the Old Testament Scriptures (cf. Peterson 2002:126).

However, despite viewing Psalms 95:7 as the probable background of 'the word of God' in Hebrews 4:12, there is some support for viewing the reference to God's word as 'living' as an echo to Deuteronomy 32:47. Ellingworth (1993:261) notes the thematic association between the two, while Allen (2007a:104-107) classifies the phrase as an echo to Deuteronomy 32:47. Although Hebrews 4:12's Z̃̃v ... ó

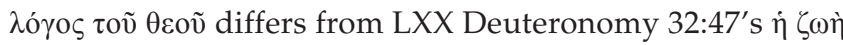
v่ $\mu \tilde{\omega} v$, Allen (2007a:106) regards Hebrews 4:12's affinity with Deuteronomy 32:47 as 'impressive' because ' $[i]$ ts context is analogous to the post-wilderness, Canaan entry backdrop that has formed the basis for Hebrews 3:7-4:11'. Allen (2007a:106-107) argues that just like the writer of Hebrews reminds his addressees that obedience to God's word is necessary to enter God's rest (4:11-12), so the post-wilderness rebellion generation of Deuteronomy is reminded not to rebel against the word of $\mathrm{YHWH}$, for this word is their life, and will bring them life in the Promised Land.

Allen's (2007a) arguments are intriguing. However, Deuteronomy 32:47 does not contain any trace of God's word discerning and exposing the intention of the heart. Moreover, Deuteronomy 32:47 does not have to be the background of Hebrews 4:12. ${ }^{37}$ The primary allusion in 4:12 remains Psalms

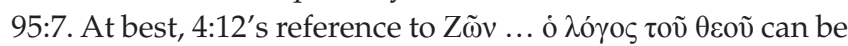
viewed as an echo to Deuteronomy's concept of life as expressed in Deuteronomy 32:47.

\section{The new and living way (10:20)}

The conclusion of the writer of Hebrews' extended exposition of Christ's high priestly ministry invites the addressees to draw near to God with complete confidence on 'the new and

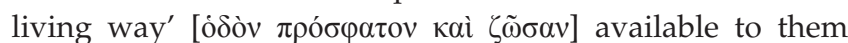
through the blood of Jesus (Heb 10:19-25).

35.Cockerill (2012:215) refers to the 'total effectiveness' of God's word.

36.It is highly unlikely a reference to Christ as the Logos (contra Allen 2010:285-286). Nothing in the immediate context leads to this interpretation.

37.Ellingworth (1993:261), for example, argues that Hebrews 4:12 'has much in common' with Wisdom 7:22-8:1.
Although the interpretation and translation of Hebrews 10:19-20 are 'unusually difficult' (Lane 1991), weighing all the different arguments, the writer seems to say the following:

He and his addressees ('we') have the privilege and right to approach God ('to enter the holy places') with confidence (or 'boldness'; $\pi \alpha \rho \rho \eta \sigma i \alpha$ ) because of the sacrifice of Jesus ('by the blood of Jesus'). This way of approaching God did not exist

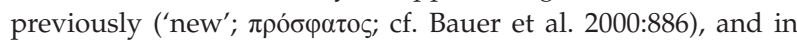
some way it is related to life ('living'). It was inaugurated ('opened'; $\dot{\gamma} \gamma \alpha \omega v i \zeta \omega)$ for them through Jesus' sacrifice ('through the curtain, that is, through his flesh'). (p. 282)

If the interpretation above is correct, the sacrificial imagery points to the interpretation of 'the living way' as 'the way that leads to life' (cf. Cockerill 2012:468; Lane 1991:283), in the sense that it gives noncondemning, encouraging access to God. The death of Christ led to life as God intended for the hearers, now and eternally (cf. Ellingworth 1993:519), namely, a life where people approach and worship and serve him gratefully, joyously and reverently. In what follows, the hearers are strongly encouraged to take advantage of this wonderful access to God (10:22-25).

In a sense, the writer of Hebrews could have had the reference to Deuteronomy 30:6 in the back of his mind as he came to the summary and application of his argument of 7:1-10:18 in 10:19-25. One could argue that the writer of Hebrews indicates in 10:19-20 that YHWH's promise to enable his people to truly live as promised in Deuteronomy 30:6 was fulfilled through his Son's suffering and death. However, it seems unlikely because he makes no reference to the circumcision of the heart, and nothing in the context guides us in the direction of Deuteronomy. ${ }^{38}$ If there is a Deuteronomic echo in this reference to life, it is quite indistinct. The background is much more likely the promise of the new covenant found in Jeremiah 31, quoted and discussed in Hebrews 8 and 10.

\section{Be subject to the Father of spirits and live (12:9)}

In 12:4-13, the writer of Hebrews exhorts his hearers to persevere in the midst of trials, articulated here as God's 'discipline' ( $\pi \alpha 1 \delta \varepsilon i \alpha)$. Quoting Proverbs 3:11-12, he urges them not to regard the discipline of the Lord lightly, but to see it as an expression of his love and an indication that he is treating them like sons. This he underscores in verse 9-10 with two a fortiori arguments, which compares the discipline of the hearers' earthly fathers with that of God, and the results of both.

The a fortiori argument in 12:9 asks: 'Shall we not much more be subject to the Father of spirits and live?' (ov̉ $\pi \mathrm{o} \lambda \dot{v}$

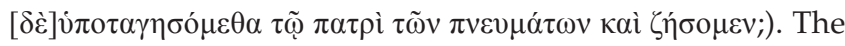
result of subjection to the Father, which forms the climax of the argument in 12:9 (cf. Attridge 1989:362), is described as life.

38.The possibility that Hebrews 10:20 echoes Deuteronomy 32:47 (this "word ... is your life') is just as unlikely because the former contains no mention of God's word and the latter does not contain a key phrase found in Hebrews 10:20. 
Obedience to God, which results in life, has a strong Deuteronomic ring to it. Yet, very few scholars indicate Deuteronomy as the possible background of these words. The reference to 'the Father of spirits' ( $\tau \tilde{\omega} \pi \alpha \tau \rho \grave{~} \tau \tilde{\omega} v \pi v \varepsilon v \mu \alpha ́ \tau \omega v)$ probably echoes Numbers 16:22 or 27:16 [ $\theta \varepsilon$ s̀ $\tau \tilde{\omega} v \pi v \varepsilon v \mu \alpha \dot{\tau} \tau \omega v$

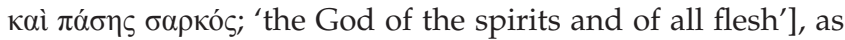
most scholars indicate. ${ }^{39}$ However, when it comes to the

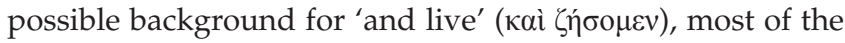
commentaries consulted are silent, or vaguely refer to Proverbs 6:23b, which says: 'the way of life [is] reproof and

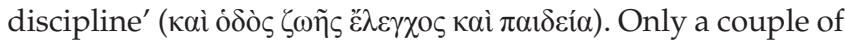
modern scholars link this reference to Deuteronomy, among others Lane (1991:424), who argues that this reference 'recalls the summons to life issued in the framework of covenant obedience in Deuteronomy 30:11-20'.

The link to Proverbs $6: 23 \mathrm{~b}$ is strengthened by its reference to 'discipline' ( $\pi \alpha 1 \delta \varepsilon i ́ \alpha)$, one of the key concepts in Hebrews 12:4-13. However, Proverbs' 'the way of life' (ódò $\zeta \omega \tilde{\eta} \varsigma$ ) is

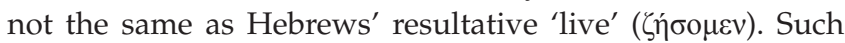
result clauses are a trademark of Deuteronomy (cf. 4:1; 6:24; $8: 1 ; 11: 8 ; 16: 20 ; 30: 6,19)$. Although Deuteronomy's standard way of indicating the result of life is not present in Hebrews (viz. i $v \alpha+$ subjunctive), ${ }^{40}$ it does contain a result clause. Moreover, the writer's reference to 'life' in 12:9 seems to indicate more than mere physical life. With this reference, the writer seems to be referring to life in its 'fullest sense' ( $\mathrm{O}^{\prime}$ Brien 2010:476), which is exactly what Deuteronomy does with its various references to well-being. Finally, other recent studies have indicated that Hebrews 12 is especially Deuteronomic (cf. Allen 2007a; Kibbe 2016), which strengthens the possibility that 12:9 could be Deuteronomic as well.

Consequently, when all of the above is taken into account, it seems more convincing to view Deuteronomy's various references to the concept of well-being as the background of Hebrews 12:9's reference to life. More specifically, if this is correct, of all the references to life as a result in obedience, the background of the reference in Hebrews 12:9 is probably Deuteronomy 8:1-5, especially 8:1 and 8:5, which refer to life as the result of obedience and the discipline of $\mathrm{YHWH}$ (Allen 2007a:86-90). ${ }^{41}$ However, the writer of Hebrews does not merely employ this concept; he alters it to refer to eternal life (cf. Cockerill 2012:625; Koester 2001:539). That is the life which God grants to those who persevere in faith and submit to him.

\section{Synthesis}

Of all the possible traces to Deuteronomy's concept of life, the most probable ones are found in Hebrews 10:31

39.Some scholars mention other possible backgrounds for this reference, including 2 Maccabees 3:24 (Ellingworth 1993:653; Moffatt 1924:203), Jubilees 10:3 (Koester 2001:529) and 1 Clement 64:1 (Koester idem).

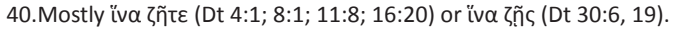

41.Allen (2007a:89) argues: 'Hebrews exegetes the quotation [of Prov 3:11-12] on the basis of Deuteronomy. 8:2-5'. Moreover, he views Hebrews $12: 7$ as an allusion to Deuteronomy 8:5. Cf. Thiessen (2009:369), who also argues that Deuteronomy 8:5 parallels Proverbs 3:11-12. However, he $(2009: 374)$ argues that 'the author uses proverbs 3.11-12 and not Deuteronomy 8.5, since the Proverbs citation can be Proverbs $3.11-12$ and not Deuteronomy 8.5,
used as a direct exhortation to his readers'.
(Dt 32:40-42), 12:9 (Dt 8:1) and 12:22 (Dt 5:26). In my opinion, the most convincing trace is found in 12:9.

However, the question remains whether Hebrews deliberately makes use of Deuteronomy's concept of life, or whether these references are part and parcel of the numerous quotations, allusions and echoes from Deuteronomy. The latter seems more likely, particularly in the light of previous studies that indicate that Hebrews focuses on the final chapters of Deuteronomy, especially the Song of Moses (cf. Allen 2007a:119-120; Moyise \& Menken 2007:4), and the observation that the majority of quotations from and allusions to Deuteronomy appear in the latter part of Hebrews (Ellingworth 1993:39; Kibbe 2016:121; Steyn 2007:153).

Consequently, it is difficult to prove the deliberate use of Deuteronomy's concept of life in Hebrews. However, the overall parallel between the two texts in terms of the concept of life is clear: Hebrews, just like Deuteronomy, urges its addressees on the edge of a great crossroad to wholeheartedly obey the living God who revealed himself to them, so that they can live.

\section{Acknowledgement Competing interest}

The author has declared that no competing interests exist.

\section{Author contributions}

I declare that I am the sole author of this research article.

\section{Ethical consideration}

This article followed all ethical standards for carrying out research without direct contact with human or animal subjects.

\section{Funding}

This research received no specific grant from any funding agency in the public, commercial or not-for-profit sectors.

\section{Data availability statement}

Data sharing is not applicable to this article as no new data were created or analysed in this study.

\section{Disclaimer}

The views and opinions expressed in this article are those of the author and do not necessarily reflect the official policy or position of any affiliated agency of the author.

\section{References}

Allen, D.L., 2010, Hebrews: The New American commentary, vol. 35, Broadman \& Holman Publishers, Nashville, TN.

Allen, D.M., 2007a, Deuteronomic representation in a word of exhortation: An assessment of the paraenitic function of Deuteronomy in the letter to the Hebrews, University of Edinburgh, Edinburgh.

Allen, D.M., 2007b, 'More than numbers: Deuteronomic influence in Hebrews 3:7-4:11', Tyndale Bulletin 58(1), 129-149. 
Attridge, H.W., 1989, The Epistle to the Hebrews: Hermeneia, Fortress Press, Philadelphia, PA.

Bauer, W., Danker, F.W., Arndt, W.F. \& Gingrich, F.W., 2000, A Greek-English Lexicon of the New Testament and other early Christian literature, Based on Walter Bauer's Griechisch-deutsches Worterbuchzu den Schriften des Neuen Testaments und de fohrchristlichen [sic] Literatur, 6th edn., University of Chicago Press, Chicago, IL.

Cockerill, G.L., 2012, The Epistle to the Hebrews: The New International commentary on the New Testament, Eerdmans, Grand Rapids, MI.

Coetsee, A.J., 2019, 'YHWH and Israel in terms of the Concept of Life in Deuteronomy', Old Testament Essays 32(1), 101-126.

Docherty, S.E., 2009. The use of the Old Testament in Hebrews: A case study in early Jewish Bible interpretation, Wissenschaftliche Untersuchungen zum Neuen Testament 260, Mohr Siebeck, Tübingen.

Dyer, B.R., 2013, 'The Epistle to the Hebrews in recent research: Studies on the author's identity, his use of the Old Testament, and theology', Journal of GrecoRoman Christianity and Judaism 9, 104-131.

Ellingworth, P., 1993, The Epistle to the Hebrews: The New International Greek Testament Commentary, Eerdmans, Grand Rapids, MI.

Gerleman, G., 1997, 'היחyhy to live', in E. Jenni \& C. Westermann (eds.), Theological Lexicon of the Old Testament, transl. M.E. Biddle, vol. 1, pp. 411-417, Hendrickson Publishers, Peabody, MA.

Gheorghita, R., 2003, The role of the Septuagint in Hebrews: An investigation of its influence with special consideration to the use of $\mathrm{Hab} 2: 3-4$ in $\mathrm{Heb} 10: 37-38$, Wissenschaftliche Untersuchungenzum Neuen Testament 160, Mohr Siebeck, Tübingen.

Guthrie, G.H., 2007, 'Hebrews', in G.K. Beale \& D.A. Carson (eds.), Commentary on the New Testament use of the Old Testament, pp. 919-995, Baker Academic, Grand Rapids, MI.

Katz, P., 1958, 'The quotations from Deuteronomy in Hebrews', Zeitschrift für die Neutestamentliche Wissenschaft 49(1), 213-223. https://doi.org/10.1515/ zntw.1958.49.1.213

Kibbe, M.H., 2016, Godly fear or ungodly failure? Hebrews 12 and the Sina Theophanies, Beiheftezur Zeitschrift für die neutestamentliche Wissenschaft 216, De Gruyter, Berlin.

Koester, C.R., 2001, Hebrews: A new translation with introduction and commentary. The Anchor Bible, vol. 36, Yale University Press, New Haven, CT.

Lane, W.L., 1991, Hebrews 9-13: Word Biblical Commentary, vol 47B, Thomas Nelson Publishers, Nashville, TN.

Liddell, H.G., Scott, R. \& Jones, H.S., 1996. A Greek-English Lexicon, 9th edn., with revised supplement, Clarendon Press, Oxford.

Markl, D., 2014, 'This word is your life: The theology of "life" in Deuteronomy', in D. Markl, C. Paganini \& S. Paganini (eds.), Gottes Wort imMenschenwort. Festschrift für Georg Fischer SJ zum 60. Geburtstag, ÖBS 43, pp. 71-96, Peter Lang, Frakfurt am Main.
McCarthy, C., 2007, Deuteronomy: Biblia Hebraica Quinta (edition cum apparatu critic noviscuriselaborato), Fascicle 5, Deutsche Bibelgesellschaft, Stuttgart.

Moffatt, J., 1924, A critical and exegetical commentary on the Epistle to the Hebrews: The International Critical Commentary, T\&T Clark, Edinburgh.

Moyise, S. \& Menken, M.J.J. (eds.), 2004, The Psalms in the New Testament: The New Testament and the Scriptures of Israel, T\&T Clark, London.

Moyise, S. \& Menken, M.J.J. (eds.), 2005, Isaiah in the New Testament: The New Testament and the Scriptures of Israel, T\&T Clark, London.

Moyise, S. \& Menken, M.J.J. (eds.), 2007, Deuteronomy in the New Testament: The New Testament and the Scriptures of Israel, Library of New Testament Studies 358, T\&T Clark, London.

O'Brien, P.T., 2010, The Letter to the Hebrews. The Pillar New Testament Commentary, Eerdmans, Grand Rapids, MI.

Oropeza, B.J. \& Moyise, S. (eds.), 2016, Exploring intertextuality: Diverse strategies for New Testament interpretation of texts, Cascade Books, Eugene, OR.

Peterson, D., 2002, 'God and Scripture in Hebrews', in P. Helm \& C.R. Trueman (eds.) The trustworthiness of God: Perspectives on the nature of Scripture, pp. 118-138, Eerdmans, Grand Rapids, MI.

Rahlfs, A., 1996, Septuaginta, Deutsche Bibelstiftung, Stuttgart.

Rascher, A., 2007, Schriftauslegung und Christologieim Hebräerbrief, Beiheftezur Zeitschrift für die neutestamentliche Wissenschaft 153, De Gruyter, Berlin.

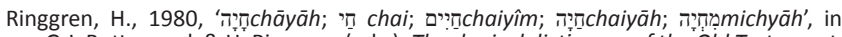
G.J. Botterweck \& H. Ringgren (eds.), Theological dictionary of the Old Testament, transl. J.T. Willis, vol. 4, pp. 324-344, Eerdmans, Grand Rapids, MI.

Smillie, G.R., 2004, 'О ^ОГОг TOY $\Theta E O Y$ in Hebrews 4:12-13', NovumTestamentum 46(4), 338-359. https://doi.org/10.1163/1568536042650649

Smith, C.R., 2012, Deuteronomy/Hebrews: Understanding the books of the Bible, IVP Connect, Downers Grove, IL.

Steyn, G.J., 2007, 'Deuteronomy in Hebrews', in S. Moyise \& M.J.J. Menken (eds.), Deuteronomy in the New Testament: The New Testament and the Scriptures of Israel, pp. 152-168, T\&T Clark, New York.

Thiessen, M., 2009, 'Hebrews 12.5-13, the Wilderness Period, and Israel's discipline', New Testament Studies 55(3), 366-379. https://doi.org/10.1017/S002868850 New Testam
9000277

Tigay, J.H., 1996, The JPS Torah Commentary: Deuteronomy, Jewish Publication Society, Philadelphia, PA.

Weinfeld, M., 1991, Deuteronomy 1-11: The Anchor Bible, vol. 5, Doubleday, New York.

Weiss, H.F., 1991, Der Brief an die Hebräer: Kritisch-exegetischer Kommentarüber das Neue Testament, Band 13, Vandenhoeck \& Ruprech, Göttingen.

Wevers, J.W., 2006, Deuteronomium: Septuaginta Vetus Testamentum Graecum, vol. III 2, Auflage, Vandenhoeck \& Ruprecht, Göttingen. 